\title{
Pigment system of cyanobacteria in the presence of heavy metals
}

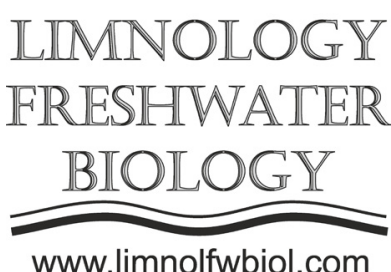

\author{
Galperina A.R.* \\ FSBEI HE “The Astrakhan state technical university”, Tatishcheva, 16, Astrakhan, 414056, Russia
}

\begin{abstract}
In the conditions of a model laboratory experiment the influence of silver, cadmium, lead, copper salts and different lead salts (an acetate and nitrate) on pigment system of filamentous cyanobacteria was studied. It was revealed that silver ions have the maximum toxic effect (cyanobacteria development was observed at a concentration of $0.002 \mathrm{mg} / \mathrm{l}$ ), and lead ions have the least toxic effect (cyanobacteria development was observed at concentrations of $0.002-20 \mathrm{mg} / \mathrm{l}$ ). It was noted that the studied heavy metals in low concentrations $(0.002-0.02 \mathrm{mg} / \mathrm{l})$ stimulate the formation of chlorophyll $a$ up to $216 \%$, carotenoids up to $133 \%$ and phycobilin pigments up to 50 times. It was found that lead acetate has a stimulating effect on the synthesis of photosynthetic pigments. The content of chlorophyll $a$ grew by $30.6 \%$, carotenoids - by $24.0 \%$ at one Maximum Permissible Concentration (MPC). Lead nitrate had the expressed inhibiting effect on synthesis of photosynthetic pigments. Depression of concentration of chlorophyll $a$ and carotenoids by $38.8 \%$ and $79.4 \%$ respectively was observed already at one maximum allowable concentration. The stimulating effect of lead acetate is noted on synthesis of phycocyanin (by 94.0\%) and allophycocyanin (by 120.0\%) in concentration up to 5 times of the MPC; the stimulating effect of lead nitrate was observed on synthesis of phycocyanin (by $64.7 \%$ ) in concentration up to 5 times of the MPC and on synthesis of allophycocyanin (up to 140.0\%) and on phycoerythrin (up to $228.0 \%$ ) at concentration up to 10 times of the MPC. Comparison of influence of various lead salts on filamentous cyanobacteria revealed a more expressed inhibiting effect of the nitrate form of lead in comparison with acetate.
\end{abstract}

Keywords: heavy metals; cyanobacteria; lead; photosynthetic pigments

One of the most significant functions of cyanobacterias is the capability of bioaccumulation and detoxication of heavy metals. Also, their response reactions (sizes, morphology, ultrastructure of the cells and physiologic-biochemical features) to the impact of anthropogenic factors are the fastest and can be representative indicators of the condition of ecosystems (Bekasova et al., 2002; Dubey et al., 2011; Fokina et al., 2017). Therefore, research focused on the morphological and physiological-biochemical parameters of cyanobacteria under the impact of heavy metals is of great relevance. The objective of this paper was evaluation of impact of heavy metals (lead, cadmium, copper, silver) on the pigment complex of filamentous cyanobacteria.

The object of the research was a phycologically pure culture of filamentous cyanobacteria. The cyanobacteria were cultivated on a BG-11 media in Erlenmeyer flasks at the temperature of $20 \pm 2{ }^{\circ} \mathrm{C}$ and in constant artificial illumination of 1500 lux. Silver was introduced to the media in $\mathrm{AgNO}_{3}$ cadmium $\mathrm{CdCl}_{2}$, lead - $\mathrm{Pb}\left(\mathrm{CH}_{3} \mathrm{COO}\right)_{2}$, copper - $\mathrm{CuSO}_{4}$. The toxicity of heavy metals was evaluated by their concentrations: $200 \mathrm{mg} / \mathrm{l} ; 20 \mathrm{mg} / \mathrm{l} ; 2 \mathrm{mg} / \mathrm{l} ; 0,2 \mathrm{mg} / \mathrm{l} ; 0,02 \mathrm{mg} / 1$ 0,002 $\mathrm{mg} / \mathrm{l}$.

The next step was to assess the impact of lead salts: acetate $\left(\mathrm{Pb}\left(\mathrm{CH}_{3} \mathrm{COO}\right)_{2}\right)$ and nitrate $\left(\mathrm{Pb}\left(\mathrm{NO}_{3}\right)_{2}\right)$ In the experiment, we used $1,5,10,15,20$ MPC concentrations of lead (Maximum Permissible Concentration, MPC, of lead for surface water of water bodies is $0.1 \mathrm{mg} / \mathrm{l}$ ). The pigment complex of the cyanobacteria was assessed according to the content of chlorophyll $a$, carotenoids and phycobiliproteins. It was established that the studied cyanobacteria withstand up to $20 \mathrm{mg} / 1 \mathrm{~Pb}\left(\mathrm{CH}_{3} \mathrm{COO}\right)_{2}$, up to $0.02 \mathrm{mg} / 1$ $\mathrm{CdCl}_{2}$, up to $0.02 \mathrm{mg} / 1 \mathrm{CuSO}_{4}$, up to $0.002 \mathrm{mg} / 1 \mathrm{AgNO}_{3}$. The manifestation of the toxic effect of heavy metals decreased in the following sequence $\mathrm{Ag}>\mathrm{Cu}>\mathrm{Cd}>$ $\mathrm{Pb}$. The toxic effect of heavy metals on cyanobacteria was accompanied by physiological changes in the cells. The presence of all metals at a concentration of 0.002 $\mathrm{mg} / \mathrm{l}$ contributed to an increase in the chlorophyll $a$ content from $116 \%\left(\mathrm{CdCl}_{2}\right)$ to $216 \%\left(\mathrm{~Pb}\left(\mathrm{CH}_{3} \mathrm{COO}\right)_{2}\right)$ compared to the control. All metals in a concentration 
of $0.002 \mathrm{mg} / \mathrm{l}$ have a stimulating effect on the content of carotenoids; the maximum effect is expressed when $\mathrm{AgNO}_{3}$ is added - 133\%. Phycobilin pigments were more sensitive to the effects of toxicants. Cadmium possessed the maximum stimulating effect. At concentrations of $0.002 \mathrm{mg} / 1$ and $0.02 \mathrm{mg} / 1$ there was an increase in the synthesis of phycocyanin up to 8 times, allophycocyanin up to 3 times, phycoerythrin up to 50 times compared with the control.

Thus, the adaptation of cyanobacteria to heavy metals was noted, which was expressed in a change in the photosynthetic system. It was revealed that the studied heavy metals in low concentrations (0.002$0.02 \mathrm{mg} / \mathrm{l})$ stimulate the formation of chlorophyll $a$, carotenoids and phycobilin pigments.

A study of the effects of lead acetate $\left(\mathrm{Pb}\left(\mathrm{CH}_{3} \mathrm{COO}\right)_{2}\right)$ and lead nitrate $\left(\mathrm{Pb}\left(\mathrm{NO}_{3}\right)_{2}\right)$ in the concentration range from 1 to 25 MPC (by lead ion) showed a maximum decrease in the concentration of chlorophyll $a$ when adding 20 and 25 MPC of lead acetate and lead nitrate, respectively.

It has been established that lead acetate has a stimulating effect on the synthesis of photosynthetic pigments. The content of chlorophyll $a$ increased by $30.6 \%$, carotenoids - by $24.0 \%$ at a concentration of 1 MPC. Lead nitrate has a pronounced inhibitory effect on the synthesis of photosynthetic pigments. Inhibition of the concentration of chlorophyll $a$ and carotenoids by $38.8 \%$ and $79.4 \%$, respectively, was already observed at 1 MPC. Thus, in the course of experimental studies, it was noted that, compared with the synthesis of carotenoids, the process of chlorophyll $a$ biosynthesis is less sensitive to the action of lead salts. Moreover, increased pigment synthesis may be associated with the manifestation of a protective reaction of the cell to the action of a toxicant and indicates the presence of a mechanism of adaptation to lead in the cyanobacteria under study. The stimulating effect of lead acetate on the synthesis of phycocyanin (by 94.0\%) and allophycocyanin (by 120.0\%) at a concentration of up to 5 MPC was noted; lead nitrate for the synthesis of phycocyanin (64.7\%) at a concentration of up to 5 MPC; for the synthesis of allophycocyanin (up to 140.0\%) and phycoerythrin (up to $228.0 \%$ ) at a concentration of up to 10 MPC. Comparison of influence of various lead salts on filamentous cyanobacteria revealed a more expressed inhibiting effect of the nitrate form of lead in comparison with acetate.

Thus, during the studies, the degree of manifestation of the toxic effect of heavy metals was determined; it decreased from silver to lead: $\mathrm{Ag}>\mathrm{Cu}>$ $\mathrm{Cd}>\mathrm{Pb}$. It was revealed that the studied heavy metals in low concentrations (0.002-0.02 $\mathrm{mg} / \mathrm{l})$ stimulate the formation of chlorophyll $a$, carotenoids and phycobilin pigments. The tested cyanobacteria show resistance to lead salts. Of all the pigments, chlorophyll $a$ is the least sensitive to lead. The nitrate form of lead inhibits the pigment system of cyanobacteria more intensively than acetate.

\section{References}

Bekasova O.D., Brekhovskikh A.A., Moskvina M.I. 2002. Participation of extracellular polysaccharides in detoxication of cadmium ions by cyanobacteria Nostoc muscorum. Biophysics 47: 515-523.

Dubey S.K., Mehra J.S., Tiwari P. et al. 2011. Potential use cyanobacterial species in bioremediation of industrial effluents. African Journal of Biotechnology 10(7): 11251132. DOI: $10.3389 /$ fpls.2016.00303

Fokina A.I., Ogorodnikova S.Yu., Domracheva L.I. et al. 2017. Cyanobacteria as test organisms and biosorbents. Pochvovedeniye [Soil Science] 1: 77-85. DOI: 10.7868/ S0032180X16110034 (in Russian) 